\title{
Effect of Foreign Equity Gross Purchases on Stock Market Volatility in Kenya : Empirical Evidence from Nairobi Securities Exchange
}

\author{
Isaac Linus Ochieng (MSC) \\ Tobias O. Olweny (PhD) \\ Oluoch J. Oluoch (PhD) \\ Gordon O. Ochere (PhD)
}

Department of Economics, Accounting and Finance

Jomo Kenyatta University of Agriculture and Technology, Nairobi, Kenya

URL:http://dx.doi.org/10.19044/esj.2019.v15n7p1

\begin{abstract}
The main objective of the study was to determine the effect of foreign equity purchases turn-over on the level of volatility at the Nairobi Securities Exchange. The study was twofold as it focused on the effect of foreign equity gross purchases on stock market volatility before and after introducing foreign exchange rate as a moderating variable. The span of the study was eight years from 2008 to 2015 as the period was marked by unprecedented world events such as the global economic recession and the post poll pandemonium in Kenya which subsequently affected foreign equity flows and the volatility in the equity bourse. The research design employed in the study was the causal research design. The target population of the study were the monthly foreign equity gross purchases, monthly Nairobi Securities Exchange 20 share indices and monthly USD Bid-Ask foreign exchange. The study samples in the study were the monthly foreign equity gross purchases, monthly Nairobi Securities Exchange 20 share indices and monthly USD Bid-Ask foreign exchange from May 2008 to December, 2015. Time series secondary data was used in the study. The data was subjected to diagnostic tests such as linearity test, multicollinearity test, normality test, test for homoscedasticity and test for autocorrelation with E-views being the main statistical tool of analysis. The main model used in the study was the vector error correction model subsequent to undertaking stationarity test, lag selection test and cointegration tests. Study results reveal a positive but in-significant effect of foreign equity purchases turn-over on stock market volatility and a negative but in-significant effect after introducing foreign exchange rate as a moderating variable. The study recommends adoption of efficacious cross-border listing rules to spur stock
\end{abstract}


market integration that would subsequently increase foreign investor participation and development of apt financial derivative markets to aid in the mitigation of time-varying foreign currency risks as a consequence of foreign exchange risk exposure.

Keywords: Foreign Equity Flows, Stock Market Volatility, Lag selection, Cointegration

\subsection{Introduction}

Foreign equity gross purchases are the total monetary values or the turn-over values of stocks purchased by foreign investors in a local stock market on a daily basis, monthly basis or annually with the possibility of analysing its short term, intermediate and long term effect on stock market volatility being postulated in both theoretical and empirical literature (Pavabutr, 2007). Wang (2009) examines the causal relationship between foreign ownership and stock market volatility in Indonesia using daily foreign holdings of Indonesian stocks from January 1996 to December, 2000. Using daily foreign equity aggregate purchases from Jakarta Stock Exchange, he finds that foreign investors prefer to hold stock with low historical volatility. Other findings indicate that foreign equity gross purchases are positively correlated with contemporaneous stock market volatility and that the level of stock market volatility increases with the level of foreign equity flows.

Hsu and Huang (2010) studied the effect of foreign equity gross purchases on stock market volatility in Taiwan after the Taiwan stock market was opened to foreign investment participants. Using daily data from 1995 to 2007 and employing a GJR-GARCH model, they find that the Taiwanese stock market become more stable after it fully opened. Lin, Lee and Chiu (2010) also used an auto-regressive jump intensity (ARJI) model to explore the stock market volatility in Taiwan subsequent to the opening of the Taiwanese stock exchange (TWSE) to foreign investors. Using daily data from 1995 to 2005 they find that TWSE tended towards greater stability during the post financial liberalization period, hence foreign investor participation in the TWSE reported in-significant effect on the TWSE volatility.

Cheng, Huang and Chen (2011) applied an EGARCH model to determine the impact of removing foreign institutional quota on the stock market volatility using daily data from 2003 in Taiwan. They find that lifting foreign ownership quotas enhanced the value of Taiwanese listed electronics companies with a low overall effect on the volatility of TWSE. Dijk and Vagias (2010) examine the relationship subsisting between international flows and liquidity and market volatility. They estimate vector auto regressions with monthly U.S. equity portfolio flows and local stock market liquidity and volatility for 46 countries in six regions over 19895-2008. They find that 
foreign equity flows to developed Europe and Asia/Pacific are positively related to local market liquidity with the analysis lending little support to the view that foreign investors destabilize local markets through an adverse impact on liquidity and volatility.

Hsu (2013) analysed the influence of foreign portfolio investment on domestic stock markets volatility in Taiwan. He uses daily closing equity aggregate purchases of stocks listed on the TWSE from 2007 to 2011 and divided equities into foreign investor favoured and un-favoured stocks by foreign investors. The findings of the study revealed that market participants did not herd in the foreign investor favoured stock group but herded in the unfavoured group only in bear markets and that the foreign investor favoured group out-perfomed the other only during economic expansion. During recession, the foreign investor un-favoured group perfomed better.

\section{Justification of the Study}

Stock market volatility is a pertinent phenomenon in emerging stock markets. A key feature emerging stock markets without the exception of Africa is high volatility. The baneful effects of high volatility which include increasing cost of capital and inhibiting long run stock market development cannot be ignored (Patro \& Wald, 2005). It is on these premise that this study sought to embolden the subsisting literature on stock market volatility by ascertaining whether foreign equity purchases turn-over positively or negatively affect the stock market volatility at Nairobi Securities Exchange as an emerging stock market bourse.

The study was significant to policy makers such as the Capital Markets Authority as it is now probable to predict how foreign equity investor participation affect fluctuations at the Nairobi Security Exchange in Kenya further bridging the perennial asymmetric information gap between foreign investors and local equity investors.

\section{Literature Review}

Loncan and Caldeira (2015) study the correlation subsisting between foreign gross purchases as a component of foreign equity capital flows and stock market returns in Brazil. The seminal paper was looked at through a six factor Arbitrage Pricing Theory model in which an additional risk factor for foreign equity flows was included. In the study, Loncan and Caldeira (2015), first undertaken an aggregate analysis, the partial effect of foreign equity flows on the IBOVESPA index's returns was statistically significant and positive. Second, Loncan and Caldeira (2015) use a disaggregate analysis was executed, in the analysis, foreign equity flows were sorted by sector of economic activity, level of corporate governance and ultimately the level of risk. The study revealed that foreign equity flows cause increases in stock market 
volatility more fundamentally to sectors related to commodities, industry and cyclical consumption. Further, for the equity organized by risk (stock betas were used as risk parameter for sorting), foreign equity flows increased the return, volatility of mid-high and high beta equity but the volatility of returns of low and low-mid beta equity decreased. However, corporate governance equity experienced a statistically significant revaluation effect.

Errunza and Miller (2000), Chari and Henry (2004), Patro and Wald (2005), Christoffer (2006), studied the effect of foreign equity flows on the cost of equity capital and return volatility at firm level. They delved on the foreign gross purchases that were subsequent to key liberalization events and how these events were correlated to stock market volatility. Farther, stock returns were compared before and after market integration. The main methodology used in all these studies was event study. The general conclusion was that foreign equity flows was associated to an increase in stock market return volatility. Bekaert and Harvey (2000) employed a regression between dividend yield, a dummy variable for liberalization events and foreign equity flow and found that dividend yield declined as a function of liberalization buttressing the hypothesis that foreign equity flows reduce the cost of equity capital. Errunza and Miller (2000) farther studied the impact of foreign equity flows on the rate of return of equity capital analysing whether firms that issued ADRs (American Depositary Receipts) in the U.S. stock market experienced a reduction on the rate of return or volatility. They find that after the issuance of the ADRs. The firms that issue them experienced higher returns as a consequence of risk sharing between domestic and international investors.

\subsection{Data and Methodology}

The study was anchored on the positivist research paradigm with causal research design being used. Secondary data was used in the study with monthly foreign equity purchases data, monthly NSE-20 share index numbers and monthly USD foreign exchange rate Bid-Ask used from 2008 to 2015 period. The vector error correction model (VECM) was the main and the most efficacious model used in the study of foreign equity flows on stock market volatility in Kenya. VECM is a type of time series model with a chain of dynamic equations capable of determining the inter-relationships between various variables (Saunders, 2009). The simplified version of the VECM model is defined as follows:

$\boldsymbol{F E F}_{t, 1}=\boldsymbol{\beta}_{10}+\boldsymbol{\beta}_{11} F E F_{t-1}+\boldsymbol{\beta}_{12} F E F_{t-2}+\ldots+\boldsymbol{\beta}_{n n} F P F_{t-n}+\boldsymbol{S M V}_{t, 1}+\boldsymbol{\mu}$ (3.1) $S M V_{t, 1}=\boldsymbol{\beta}_{20}+\boldsymbol{\beta}_{21} S M V t-1+\boldsymbol{\beta}_{22} S M V_{t-2}+\ldots+\boldsymbol{\beta}_{n n} S M V_{t-n}+\boldsymbol{F E F} \boldsymbol{F}_{t, 1}+\boldsymbol{\mu}$ (3.2)

Concisely written as:

$\left(\begin{array}{l}\text { Flows t } \\ \text { SMV }_{\mathrm{t}}\end{array}\right)=\left(\begin{array}{l}\alpha_{\mathrm{f}} \\ \alpha_{\mathrm{r}}\end{array}\right)+\sum_{k=0}^{n} \quad\left(\begin{array}{rr}\beta_{11, t-1} & \beta_{12, t-2} \\ \beta_{21}, t-1 & \beta_{22, t-2}\end{array}\right)++\left(\begin{array}{r}\text { SMV t } \\ \text { Flows t }\end{array}\right)+\left(\begin{array}{l}\varepsilon_{1 \mathrm{t}} \\ \varepsilon_{2 \mathrm{t}}\end{array}\right)$ 
Where FEF t, 1 is the current foreign equity flow and FEF t-1, FEF t-2, and $\mathrm{FEF}_{\mathrm{t}-\mathrm{n}}$ are lagged values of foreign equity gross purchases and $\mathrm{SMV} \mathrm{t}, 1$ is the current market volatility in equation (3.1) whereas SMV t, 1 is the current stock market volatility and SMV t-1, SMV t-2, SMV t-n are lagged values of stock market volatility and $\mathrm{FEF}_{\mathrm{t}, 1}$ is the current foreign equity flow in equation (3.2). $\beta_{11}, \beta_{12}, \beta_{\mathrm{nn},} \beta_{21}, \beta_{22}$, and $\beta$ nn are beta coefficients and $\beta_{10}$ and $\beta_{20}$ are constant variables and $\mu$ is the white noise in both equations.

\section{Diagnostic Tests}

The first test that was undertaken in the time series data was stationarity test or unit root test. In this study Augmented Dickey-Fuller Test (ADF) was used to test for stationarity. Johansen Co-Integration Tests was performed to determine the subsistence of long term correlation between the dependent and the independent variable as per the postulations of (Lutkepohl, 2007). While running a time series model, lag lengths were determined in the study. Lag lengths were arrived at using four different techniques; one, Final prediction error (FP), two, Akaike information criterion (AIC), three, Schwarz information criterion (SC) and Hannan-Quinn information criterion (HQI) The lag length was arrived at by the majority of the techniques.

\section{Empirical Results}

Stationarity Test for Model without Moderation

Augmented Dickey Fuller (ADF) test was used in the study to test for stationarity.

Table 2.1 Unit Root Test (Level)

\begin{tabular}{lllll}
\hline Variable & & \multicolumn{2}{l}{ ADF Test at levels } & \\
& & T statistic & Critical Value at 5\% & P value \\
\hline SMV & Constant & -4.7 & -2.89 & 0.00 \\
& Constant and Trend & -4.67 & -3.45 & 0.00 \\
\multirow{2}{*}{ FEGP } & Constant & -2.72 & -2.89 & 0.08 \\
& Constant and Trend & -4.22 & -3.45 & 0.01 \\
\multirow{2}{*}{ FEGS } & Constant & -1.91 & -2.89 & 0.33 \\
& Constant and Trend & -6.66 & -3.45 & 0.0 \\
\multirow{3}{*}{ FEIV } & Constant & -3.16 & -2.89 & 0.03 \\
& Constant and Trend & -3.06 & -3.45 & 0.12 \\
& Constant & -2.98 & -2.89 & 0.04 \\
\multirow{2}{*}{ FER } & Constant and Trend & -4.71 & -3.45 & 0 \\
& Constant & -2.32 & -2.89 & 0.17 \\
& Constant and Trend & -3.56 & -3.45 & 0.04 \\
\hline
\end{tabular}

Augmented Dickey Fuller (ADF) test results in table 2.1 revealed that the only variable that was stationary at both trend and constant was stock 
market volatility and not foreign equity gross purchases hence warranting the need for difference at level one.

Table 2.2 Unit Root Test (First Difference)

\begin{tabular}{|c|c|c|c|c|}
\hline \multirow[t]{2}{*}{ Variable } & & \multicolumn{3}{|c|}{ ADF Test at levels } \\
\hline & & T statistic & Critical Value at $5 \%$ & $P$ value \\
\hline \multirow[t]{2}{*}{ FEGP } & Constant & -13.58 & -2.89 & 0.00 \\
\hline & Constant and Trend & -13.55 & -3.45 & 0.00 \\
\hline \multirow[t]{2}{*}{ FEGS } & Constant & -10.6 & -2.89 & 0.00 \\
\hline & Constant and Trend & -10.54 & -3.45 & 0.00 \\
\hline \multirow[t]{2}{*}{ FEIV } & Constant & -14.16 & -2.89 & 0.00 \\
\hline & Constant and Trend & -14.17 & -3.45 & 0.00 \\
\hline \multirow[t]{2}{*}{ FER } & Constant & -6.63 & -2.89 & 0.00 \\
\hline & Constant and Trend & -6.61 & -3.45 & 0.00 \\
\hline
\end{tabular}

From table 4.2 all the variables had no unit root; stationary, upon differencing indicating the possibility of using the data in the vector error correction model.

Lag Selection Criterion for Model without Moderation

Table 2.3 Lag Selection Criterion

\begin{tabular}{lllllll}
\hline Lag & LogL & LR & FPE & AIC & SC & HQ \\
\hline 0 & 302.5881 & NA & $3.45 \mathrm{e}-11$ & -7.06162 & -6.88799 & -6.99182 \\
1 & 516.9184 & 392.9390 & $4.96 \mathrm{e}-13^{*}$ & $-11.30758^{*}$ & $-10.09217^{*}$ & $-10.81900^{*}$ \\
2 & 548.8095 & $53.91124^{*}$ & $5.54 \mathrm{e}-13$ & -11.2098 & -8.95256 & -10.3024 \\
3 & 574.8398 & 40.28497 & $7.26 \mathrm{e}-13$ & -10.9724 & -7.67341 & -9.64622 \\
4 & 602.8052 & 39.28469 & $9.36 \mathrm{e}-13$ & -10.7811 & -6.44033 & -9.03613 \\
5 & 630.2971 & 34.69211 & $1.28 \mathrm{e}-12$ & -10.5785 & -5.19598 & -8.41477 \\
6 & 675.6008 & 50.69698 & $1.21 \mathrm{e}-12$ & -10.8 & -4.37572 & -8.2175 \\
7 & 712.2341 & 35.76113 & $1.54 \mathrm{e}-12$ & -10.8151 & -3.34902 & -7.8138 \\
8 & 764.0238 & 43.15810 & $1.53 \mathrm{e}-12$ & -11.191 & -2.68319 & -7.77096 \\
\hline
\end{tabular}

* indicates lag order selected by the criterion

LR: sequential modified LR test statistic (each test at 5\% level)

FPE: Final prediction error

AIC: Akaike information criterion

SC: Schwarz information criterion

HQ: Hannan-Quinn information criterion

Lag selection criteria results indicated that stock market volatility and foreign equity gross purchases were both lagged ones in the vector error correction model. 


\section{Cointegration for Model without Moderation}

Table 2.4 Johansens Cointegration for Model without Moderation

\begin{tabular}{lllll}
\hline $\begin{array}{l}\text { Hypothesized } \\
\text { No. of CE(s) }\end{array}$ & Eigen value & $\begin{array}{l}\text { Trace } \\
\text { Statistic }\end{array}$ & $\begin{array}{l}\mathbf{0 . 0 5} \\
\text { Critical Value }\end{array}$ & Prob.** \\
\hline None $*$ & 0.499 & 138.833 & 95.754 & 0.000 \\
At most * $^{*}$ & 0.261 & 77.323 & 69.819 & 0.011 \\
At most 2 & 0.234 & 50.433 & 47.856 & 0.028 \\
At most 3 & 0.158 & 26.725 & 29.797 & 0.109 \\
At most 4 & 0.108 & 11.406 & 15.495 & 0.188 \\
At most 5 & 0.014 & 1.276 & 3.841 & 0.259 \\
\hline
\end{tabular}

Trace test indicates 3 cointegrating eqn.(s) at the 0.05 level

* denotes rejection of the hypothesis at the 0.05 level

**MacKinnon-Haug-Michelis (1999) p-values

From table 2.4 the time series variables were cointegrated 3 times; at most 2, this occurrence meant that the series was in three pairs or in patterns of three hence the evidence of a long term relationship. Consequently, the best model to use in the study was Vector Error Correction Model (VECM)

\section{Vector Error Correction Model Results}

Table 2.5 Vector Error Correction Model (model without Moderation)

\begin{tabular}{lllll}
\hline & Coefficient & Std. Error & t-Statistic & Prob. \\
\hline C(1) & -0.06 & 0.03 & -2.04 & 0.04 \\
C(2) & -1.53 & 1.59 & -0.96 & 0.34 \\
C(3) & -0.24 & 0.10 & -2.35 & 0.02 \\
C(4) & 2.71 & 1.78 & 1.53 & 0.13 \\
C(5) & 0.37 & 1.36 & 0.27 & 0.79 \\
C(6) & -2.85 & 1.62 & -1.76 & 0.08 \\
C(7) & -1.05 & 1.32 & -0.80 & 0.43 \\
C(8) & -0.02 & 0.10 & -0.18 & 0.86 \\
\hline & R Squared & 0.15 & Mean of dependent variable & -0.02 \\
& Adjusted R squared & 0.07 & S.D. dependent variable & 1.00 \\
& S.E. of Regression & 0.97 & Sum Squared residuals & 77.00 \\
& Durbin-Watson & 2.03 & & \\
\hline
\end{tabular}

$\mathrm{D}(\mathrm{SMV})=\mathrm{C}(1) *(\mathrm{SMV}(-1)+46.7 * \mathrm{FEGS}(-1)+9.19 * \mathrm{FEIV}(-1)-58.31 * \mathrm{FEOV}(-1)-$

$5.41)+\mathrm{C}(2) *(\mathrm{FEGP}(-1)-0.59 * \mathrm{FEGS}(-1)-0.90 *(\mathrm{FEIV})+0.18 * \mathrm{FEOV}(-$

1) +0.12$)+\mathrm{C}(3) * \mathrm{D}(\mathrm{SMV}(-1))+\mathrm{C}(4) * \mathrm{D}(\mathrm{FEGP}(-1))+\mathrm{C}(5) * \mathrm{D}(\mathrm{FEGS}(-1))+\mathrm{C}(6) * \mathrm{D}(\mathrm{FEIV}(-$

$1))+\mathrm{C}(7) * \mathrm{D}(\mathrm{FEOV}(-1))+\mathrm{C}(8)$ 
From the VECM results in table 2.5 lagged values of foreign equity gross purchases positively affected the volatility at the stock market hence the rejection of the null hypothesis that foreign equity gross purchases do not affect stock market volatility at the Nairobi Securities Exchange with the conclusion that foreign equity gross purchases affect stock market volatility. The unidirectional relationship between foreign equity gross purchases and stock market volatility was in support of the positive feed-back theory (Warther, 1995) grounded on the notion that increases in foreign equity gross purchases results in volatility increases in the stock market. It is worth noting however, that the positive contemporaneous effect of foreign equity flows on stock market volatility was in-significant further corroborating the findings of Borenzstein and Gelos (2000) and (Loncan \& Caldeira, 2015). The disturbances in the stock market caused by the foreign equity gross purchases was attributed to information asymmetry as foreign investors harboured more information in the bourse.

Table 2.6 Vector Error Correction Model with Foreign Exchange Rate Moderation

\begin{tabular}{lllll}
\hline & Coefficient & Std. Error & t-Statistic & Prob. \\
\hline $\mathrm{C}(1)$ & -0.08 & 0.05 & -1.51 & 0.13 \\
$\mathrm{C}(2)$ & -376.97 & 85.37 & -4.42 & 0.00 \\
$\mathrm{C}(3)$ & 166.10 & 70.56 & 2.35 & 0.02 \\
$\mathrm{C}(4)$ & 330.92 & 64.20 & 5.15 & 0.00 \\
$\mathrm{C}(5)$ & -0.36 & 0.11 & -3.36 & 0.00 \\
$\mathrm{C}(6)$ & 175.36 & 88.16 & 1.99 & 0.05 \\
$\mathrm{C}(7)$ & -25.28 & 65.86 & -0.38 & 0.70 \\
$\mathrm{C}(8)$ & -118.56 & 85.88 & -1.38 & 0.17 \\
$\mathrm{C}(9)$ & -27.73 & 65.63 & -0.42 & 0.67 \\
$\mathrm{C}(10)$ & 6.07 & 7.56 & 0.80 & 0.42 \\
$\mathrm{C}(11)$ & -38.73 & 19.85 & -1.95 & 0.05 \\
$\mathrm{C}(12)$ & 5.91 & 14.94 & 0.40 & 0.69 \\
$\mathrm{C}(13)$ & 25.78 & 19.43 & 1.33 & 0.18 \\
$\mathrm{C}(14)$ & 6.16 & 14.89 & 0.41 & 0.68 \\
$\mathrm{C}(15)$ & -0.05 & 0.09 & -0.56 & 0.58 \\
\hline & R Squared & 0.44 & Mean of dependent variable & -0.02 \\
& Adjusted R squared & 0.33 & S.D. dependent variable & 1.00 \\
& S.E. of Regression & 0.82 & Sum Squared residuals & 50.48 \\
& Durbin-Watson & 1.93 & & \\
\hline
\end{tabular}

$\mathrm{D}(\mathrm{SMV})=\mathrm{C}(1) *(\mathrm{SMV}(-1)-237.44 * \mathrm{FEOV}(-1)+56.54 * \mathrm{FERV}(-1)+26.97 * \mathrm{FEGP} F \mathrm{FER}(-1)-48.04 * \mathrm{FEGS}-$ FER(-1)-29.65*FEIV_FER(-1)+88.28*FEOV_FER(-1)-229.19)+C(2)*(FEGP(-1)-0.926*FEOV(1)+0.17*FER(-1)-0.18*FEGP_FER(-1)-0.09*FEGS_FER(-1)-0.05*FEIV_FER($1)+0.28 *$ FEOV_FER(-1)-0.08*FER(-1)-0.713)+C(3)*(FEGS(-1)-1.13*FEOV(-1)-0.08*FER(-1)0.02*FEGP_FER(-1)-0.18*FEGS_FER(-1)+0.02*FEIV_FER(-1)+0.22*FEOV_FER(-

1) +0.33$)+\mathrm{C}(4) *(\mathrm{FEIV}(-1)-0.61 *$ FEOV $(-1)+0.28 *$ FER(-1)+0.06*FEGP_FER(-1)-0.14*FEGS_FER(-

1)-0.3*FEIV_FER(-1)+0.24*FEOV_FER(-1)-1.16)+C(5)*D(SMV(-1)+C(6)*D(FEGP(-

1) $+\mathrm{C}(7) * \mathrm{D}($ FEGS $(-1))+\mathrm{C}(8) * \mathrm{D}(\mathrm{FEIV}(-1))+\mathrm{C}(9) * \mathrm{D}(\mathrm{FEOV}(-1))+\mathrm{C}(10) * \mathrm{D}(\mathrm{FERV}(-$

1) $)+C(11) *$ D(FEGP_FER(-1))+C(12)*D(FEGS_FER(-1))+C(13)*D(FEIV_FER(-

$1))+C(12) *$ D(FEOV_FER(-1) $)+C(15)$ 
From the VECM results in table 2.6 lagged values of moderated foreign equity gross purchases with foreign exchange rate negatively affected the volatility at the stock market hence the rejection of the null hypothesis that moderated foreign equity gross purchases do not affect stock market volatility at the Nairobi Securities Exchange with the conclusion that foreign equity gross purchases affect stock market volatility. The bi-directional relationship between moderated foreign equity gross purchases with foreign exchange rate and stock market volatility was in support of the smoothing theory (Kalaycioglu, 2004) predicated on the notion that foreign equity gross purchases and stock market volatility have an inverse relationship. It is worth noting however, that the negative contemporaneous effect of foreign equity gross purchases on stock market volatility was in-significant further corroborating the findings of (Chang et al., 2013) who argues that any increases in equity prices causes foreign investors to withdraw from the market citing market over-reaction hence a reduction in equity prices with a subsequent reduction in stock market volatility.

\subsection{Summary, Conclusion and Recommendations}

From the hypothesis tested in the VECM model on the effect of foreign equity gross purchases on stock market volatility at the NSE, foreign equity purchases turn-over positively affected stock market volatility before incorporating foreign exchange rate as a moderating variable whereas after the interaction of foreign exchange rate with foreign equity gross purchases the effect was negative. The change in the effect from a positive effect to a negative effect upon introduction of the moderating variable was attributed to time varying risks caused by disturbances in international foreign exchange markets by major market participants. The study recommends institutionalization of operationally sustainable derivative markets that can present foreign investors with hedging options to mitigate foreign currency time-varying risks precipitated by transaction, translation and economic foreign currency risk exposure. Further, the study recommends adoption and subsequent implementation of efficacious foreign participation policies that would go a long way in increasing market integration to increase foreign investor participation such as adopting workable cross-border listing rules which will in-turn guarantee a stable sovereign credit rating that ultimately guarantees a liquid stock market. Liquid stock markets are able to absorb any possible disturbances that may emanate from foreign investor participation.

\section{References:}

1. Bekaert, G., \& Harvey, C. (2000). Forign Speculators and Emerging Equity Markets. Journal of Finance, 565-613. 
2. Chari, A., \& Henry, P. (2004). Risk Sharing and Asset Prices: Evidence from a Natural Experiment. Journal of Finance, 1295-1324.

3. Cheng, C., Huang, A. Y., \& Chen, C. C. (2011). The Effect of Abolishing a Foreign Institutional Investment Quota in Taiwan. Journal of Emerging Markets Finance and Trade Volume 47, 1-12.

4. Christoffersen, P., Chung, H., \& errunza, R. (2006). Size matters: The impact of financial liberalization on individual firms. Journal of International money and Finance, 1296-1318.

5. Errunza, R., \& Miller, P. (2000). Market Segmentation and thr cost of the capital in international equity markets. Journal of Finance and Quantitative Analysis, 577-600.

6. Hsu, C. (2013). The Influence of Foreign Portfolio Investment on Domestic Stock Returns: Evidence from Taiwan. International Journal of Business and Finance Research, 1-12.

7. Patro, D., \& Wald, J. (2005). Firm Characteristics and the Impact of Emerging Market Liberalization. Journal of Banking and Finance, 1671-1695.

8. Pavabutr, P. (2004). Foreign Portfolio Flows and Emerging Stock Markets: Lessons from Thailand. Dessertation, 1-20.

9. Loncan, R. T., \& Caldeira, J. F. (2015). Foreign Portfolio Capital Flows and Stock Returns: A Case of Brazilian Listed Firms. Journal of Economics and Finance, 1-20.

10. Wang, J. (2009). Foreign Equity Trading and Emerging Market Volatility: Evidence from Indonesia and Thailand. Journal of Development Economics, 259-292. 